This is an Accepted Manuscript of an article published by Pion Ltd. in Environment and Planning A, available online: http://www.envplan.com/abstract.cgi $\mathrm{id}=a 45370$ or http://dx.doi.org/10.1068/a45370.

This is Özlem Onaran and Valerie Boesch, 2014. The definitive, peer-reviewed and edited version of this article is published in Environment and Planning A, volume 46, issue 2, pages 373-397, 2014, doi:10.1068/a45370.

\title{
The effect of globalization on the distribution of taxes and social expenditures in Europe: Do welfare state regimes matter?
}

\author{
Özlem Onaran ${ }^{\mathrm{a}}$ and Valerie Boesch ${ }^{\mathrm{b}}$
}

\footnotetext{
a) Corresponding author, University of Greenwich, Business School, Park Row, Greenwich, London, SE10 9LS, UK, e-mail: o.onaran@gre.ac.uk, phone: +44 2083318519.

${ }^{b}$ Ministry of Social Affairs and Labor, Dept. of International Labor Market Policy A-1010 Vienna, Austria, e-mail: valerie.boesch@bmask.gv.at
}

Acknowledgements: The authors are grateful to Markus Leibrecht, Michael Klien, Oliver Prausmüller, Ilker Atac, and three anonymous referees and the editor for very helpful comments. Support from the Austrian Science Fund (FWF) Project Nr. F2008 is acknowledged. 


\title{
The effect of globalization on the distribution of taxes and social expenditures in Europe: \\ Do welfare state regimes matter?
}

\begin{abstract}
This paper estimates the effect of globalization on the implicit tax rates (ITR) on capital income, labor income and consumption, and the share of social protection expenditures in total public expenditures in Western and Eastern Europe. It tests the coexistence of efficiency and compensation effects of globalization on the expenditure and the revenue sides of government budgets. In Western Europe, globalization leads to an increase in social expenditures; however these expenditures are to an increasing extent financed by taxes on labor. There are important differences between the welfare states. In the conservative regimes, both social expenditures and taxes on labor increase due to globalization. In the social-democratic regimes social expenditures are not affected by globalization, but ITR on labor increases, whereas ITR on capital and consumption decrease as a result of globalization. In the liberal regimes, the ITR on labor is rising, while social expenditures are declining. In the southern welfare regime globalization does not have any significant effects on the distribution of taxes or social spending. In Eastern Europe, in the Baltic States globalization leads to a decrease in social spending, whereas in the other Eastern European New Member States (post-communist European regimes) there is an upward convergence in social spending due to globalization. The ITR on consumption decrease due to globalization in the post-communist European regimes, whereas in the Baltics there is no robust significant effect of globalization on taxes.
\end{abstract}

JEL Code: H23, H24, H25, H50, F19, F21

Key words: globalization, social expenditures, implicit tax rates, welfare regimes Word count: 9004 


\section{Introduction}

This paper analyses the effects of globalization on social expenditures and the distribution of taxes, i.e. the tax burden on capital income, labor income, and consumption in Western and Eastern Europe with a focus on differences between welfare regimes.

Tax competition theory argues that the increasing mobility of capital makes firms capable of avoiding taxes by choosing countries with a lower tax burden. Thus, capital mobility creates a pressure to reduce taxes on the mobile factor, which results in inefficiently low levels of capital taxes and public good provision (Oates, 1972; Zodrow and Mieszkowski, 1986). If government expenditures are held constant, a fall in capital taxes implies a shift of the tax burden to the immobile factor, i.e. labor.

Regarding the expenditure side, there are two hypotheses on the impact of globalization. The efficiency hypothesis argues that globalization leads to increasing competition among nations to attract capital. This in turn leads to an erosion in tax revenues and a decline in public expenditures (e.g. Zodrow and Mieszkowski; 1986 Garrett and Mitchell, 2001; Dreher et al., 2008a). Additionally, increasing competition changes the composition of public spending and leads to a shift from public goods to public inputs, i.e. a shift from expenditures that are mainly beneficial for residents to expenditures which aim at attracting capital (e.g. Keen and Marchand, 1997).

The alternative hypothesis argues that globalization is accompanied by an increase in spending on public goods, in particular compensating social expenditures in response to increased external risks (Rodrik, 1998; Swank, 2002; Garrett and Mitchell, 2001).

Although there is a rich empirical literature on the effects of globalization on either the spending or the revenue side of the government budget, studies that analyze the effects on both taxation and spending simultaneously are limited to Bretschger and Hettich (2002), Adam and Kammas (2007), Dreher (2006a) and Dreher et al. (2008a). There is evidence for 
a joint existence of the efficiency and compensation hypotheses, albeit via opposite effects on the two sides of the budget (Bretschger and Hettich, 2002; Adam and Kammas, 2007). On the one hand the tax burden is shifting from capital to labor. On the other hand, social expenditures are increasing due to globalization.

Our paper belongs to this strand of literature. Using two different sets of panel data for the old EU member states (EU15) and the Central and Eastern European New Member States (CEENMS), we estimate the effect of globalization on the implicit tax rates (ITR) on capital, labor and consumption, and the share of social protection expenditures in total expenditures. Most studies focus on taxes on capital and labor, and omit the taxes on consumption. We measure globalization by the multi-dimensional KOF indices (Dreher, 2006b; Dreher et al., 2008a), which capture not only the economic aspects such as trade, foreign direct investment (FDI), income payments to foreign nationals, portfolio investments, restrictions on trade and capital flows, but also the political and social dimensions of globalization.

The first contribution of our paper is the focus on EU15 and the CEENMS. Secondly, we estimate whether the effects differ between the different welfare state regimes. Leibrecht et al. (2011) and Onaran et al. (2012) are the only studies in this literature that distinguishes the effects in different welfare regimes in Western Europe, but these papers are limited to either the effects on social expenditures or taxes only, whereas this paper shows that the forces of compensation and efficiency may work differently on the revenue and expenditure sides. They also do not account for differences within the CEENMS due to the short time series they use. We use an updated data set, which allows us to distinguish different regimes in the CEENMS.

There is another strand of literature that focuses mainly on tax competition across jurisdictions based on corporate and capital gains taxes using spatial econometrics, which 
finds that corporate taxes are driven down by external tax competition rather than by internal factors (Davies et al., 2003; Davies and Voget, 2008; Devereux et al., 2008; Overesch and Rincke, 2008). However, this literature focuses on taxes on capital, whereas our focus is to test how globalization affects the revenue and expenditure sides of the budget simultaneously. Furthermore, as Devereux et al. (2008) show, competitive downward pressure on the tax rates on capital is generated by the relaxation of capital controls -a variable incorporated in the KOF globalization indices among other variables. The advantage of using a common and broad measure of globalization, as in Bretschger and Hettich (2002), Adam and Kammas (2007), Dreher (2006a) and Dreher et al. (2008), is that we can test potential effects on different tax categories as well as social spending, whereas the spatial lag would be relevant mostly for taxes on the mobile factor of production.

The paper is structured as follows: Section two reviews the welfare state literature and its relevance for the effects of globalization. Section three describes the data and stylized facts. Section four and five presents the estimation methodology and the results. Section six concludes.

\section{Welfare regimes and globalization}

Welfare regimes, and hence national economic and political institutions matter, as they shape or narrow down how states react to globalization (Campbell, 2005; Scharpf and Schmidt, 2000; Esping-Andersen, 1999). Pierson (1996) argues that cuts in welfare spending have been slow and path-dependent following the crisis of the 1970s. Different constituencies within the population and citizens' expectations of the responsibilities of the welfare states are created in an historical institutional context. Retrenchment initiatives are associated with high electoral costs; similarly existing commitments like pensions lock in policy makers (Pierson, 1996). However, path dependency does not mean that change does not occur, but it is conditional on the historical and institutional context; e.g. radical retrenchment has been 
easier when there is a significant electoral slack, or budgetary crisis (Pierson, 1996). Hacker (2004) and Streeck and Thelen (2005) argue that fundamental change can occur through incremental transformations of welfare state policies; e.g. through a slow process of privatization of welfare services. In some cases collective agreements between unions and employers may fill some gaps in welfare state provision (Trampusch, 2007; Yerkes, 2011; Johnston et al., 2011); thus an absence of spending by the state in response to globalization can be compensated for through a collectivization of risks by other actors. Change may also take the form of a shift in the focus of welfare spending under the pressure of new social risks linked to the changes in family structures, increasing female employment, working poor, precarious work, long-term unemployment rather than a complete retrenchment (Bonoli, 2007; Pierson, 2001; Taylor-Gooby, 2004, Yerkes, 2011). Globalization may have caused some of these new risks like precarious employment, but the new risks, and their consequences for the change in the welfare states are a much broader topic.

Different welfare states create different types of labor and business organizations and alliances, which have an impact on the tax and expenditures policy (Campbell, 2005). For example, in social-democratic countries tax rates on both capital and labor are the highest in Europe, since there is a consensus that the revenue is utilized to finance social expenditures. In contrast, if social expenditure is historically low, it may be difficult to increase it under the pressures of globalization, given the limits to tax increases (Kautto and Kvist, 2002).

The varieties of capitalism approach of Hall and Soskice (2001) highlights the importance of social spending to firms in coordinated market economies, where unemployment benefits with high replacement rates can facilitate workers' interest in investing in industry-specific skills, and coincide with the interests of firms in having access to pools of workers with high and specific skills. On the contrary, in the liberal welfare states, low levels of benefits coincide with firms' preferences for fluid labor markets. Thus, since 
firms have different strategies in different regimes, their demands about the responses of the states to globalization and risks also differ (Hall and Soskice, 2001). While it is likely to see cuts in social spending as a response to globalization in the liberal market economies, in the coordinated market economies the interests of both the firms and labor unions may lead to preserving social spending.

Different welfare regimes also generate different norms about tax equity. Plümper et al. (2009) show that governments are restricted in how they react to tax competition by fairness norms as much as budget constraints, which prevent a wholesale race-to-the-bottom in capital taxation.

In some cases globalization might also lead to a convergence of welfare states (Brady et al., 2005; Adelantado and Cuevas, 2006). In the case of less generous states globalization might cause upward convergence as a result of the demands of citizens in an era of political integration (Kautto and Kvist, 2002).

For Western Europe, in a widely used classification Esping-Andersen (1999) groups countries into regimes depending on the degree of stratification, decommodification ${ }^{1}$, and the mix between private and public social security institutions: the social-democratic regime (Sweden, Denmark, Finland, Norway) characterized by a high decommodification index, little stratification and state provision of social security; the conservative regime (Germany, France, Austria, Belgium, Italy, the Netherlands, Luxembourg) where social security is provided partly by the state and partly by the market, but is strongly linked to the status of employment and to families, with a medium degree of decommodification; the liberal regime (United Kingdom, Ireland, United States) characterized by low decommodification and primarily market provision of social security. Esping-Andersen's typology has been widely

${ }^{1}$ Decommodification refers to public spending that reduce the reliance of the citizens on the market for some goods and services such as unemployment benefits, health, and pension. 
discussed and criticized; e.g. it has been proposed to reconsider the classification of countries, use further indicators regarding benefits other than cash-benefits, and integrate the gender aspects (Bambra, 2006; Kasza, 2002; Leibfried, 1992). Ferrara (1996) and Bonoli (1997) suggest a fourth southern regime including Spain, Italy, Greece, and Portugal with a higher degree of polarization than in the conservative regime and persistence of clientelism in the distribution of social services. The Netherlands is also argued to be a hybrid regime, which combines corporatist social insurance for workers with universal insurances, and more recently includes also liberal elements (Arts and Gelissen, 2002; Clasen and van Oorschot, 2002). Due to its wide use in the literature, we adapt an extended version of EspingAndersen's classification by adding the southern welfare regime. We also do a robustness check by excluding the Netherlands from the sample due to its ambiguous character.

We estimate the effects in the CEENMS separately, as these countries constitute welfare regimes in transition different from those in Western Europe. The specific aspects of the macroeconomic environment in the post-transition CEECs may also justify separate estimations. Due to the transition crisis extensive financial needs emerged, caused by increasing unemployment, early pension schemes and a decline of women's participation in the labor force (Onaran, 2008). However, in an effort to attract FDI, the CEECs cut corporate income tax rates (Bellak and Leibrecht, 2009) or introduced flat rate personal income taxes (Keen et al., 2008; Brook and Leibfritz, 2005). Finally the presence of a large informal economy led many governments to decrease tax rates to encourage formalization (Duman, 2010).

Although early studies position the CEECs within the liberal regime (e.g. Ferge, 2001; Standing, 1996), later studies argue that they form a separate welfare regime (Lelkes, 2000). Orenstein and Haas (2005) group all CEECs as well as other former Yugoslav republics in a European post-communist welfare regime and argue that the prospects of joining the EU 
created a similar pattern of development via the accession process. Differently, Fenger (2007) distinguishes a "post-communist European type" (Bulgaria, Czech Republic, Hungary, Poland, Slovakia and Croatia), a "former USSR type" (Estonia, Latvia, Lithuania, Ukraine, Russia and Belarus) and a group of developing welfare states (Georgia, Romania and Moldova). The post-communist European type in Fenger mixes characteristics of both the conservative and the social-democratic types. Bohle and Greskovits (2007) distinguish further regimes: a neoliberal type in the Baltic States, an embedded neoliberal type in the Visegrad states, and a neo-corporatist type in Slovenia. Compared to the more marketoriented Baltic States, the Visegrad states are more socially inclusive. The least marketoriented type is Slovenia with social indicators closer to West European standards.

First, we estimate the effects of globalization in the CEENMS in aggregate, i.e. treating the CEENMS as a single welfare regime in transition as suggested by Orenstein and Haas (2005). Then in order to test whether there are different responses within the CEENMS, following the common point in both Fenger (2007) and Bohle and Greskovits (2007), we distinguish a separate Baltic regime, and group the other CEENMS as a post-communist European regime. It is not possible to classify Slovenia as a third regime due to the limited availability of time series data.

\section{Data and Stylized Facts}

3.1. Globalization Globalization affects the governments' decisions in several ways: Globalization may restrain governments via increased budgetary pressure due to trade liberalization and increased factor mobility. Increased world market integration through trade, FDI, portfolio investments may affect the domestic economy by increasing inequality and economic insecurity, and the citizens may seek to be compensated by the public sector. However, globalization goes beyond the economic dimensions, and incorporates also social, institutional and political aspects, exclusion of which could lead to biased estimates (Dreher 
et al., 2008a). Therefore, we employ the KOF indices of economic, social, and political globalization (Dreher, 2006b; Dreher et al., 2008a). KOFecon is composed of the actual flows-index, which includes trade, FDI, income payments to foreign nationals and portfolio investments, and the index of restrictions on trade and capital flows. KOFglobal includes KOFecon as well as the index of social globalization, which consists of data on personal contact, information flows and cultural proximity, and the index on political globalization, which consists of data on the number of embassies and the membership in international organizations. The multi-dimensional KOF indices are a better way to reflect the joint effects of globalization compared to individual variables like FDI or trade or restrictions on capital flows (Leibrecht et al., 2011). The broader index including social and political globalization can incorporate further dimensions related to the influence of the practices in other countries on the aspirations of citizens; they also help to reflect issues of convergence, which may be determined via political and legislative processes in the EU.

Figures 1 and 2 show the unweighted average KOF indices. All countries have experienced a significant and continuous increase in their exposure to globalization. The conservative and the liberal regimes show a similar development of the KOFecon, with the liberal regime's index starting to rise already in the 1970s. KOFecon in the social-democratic regime started at a lower level, but experienced the highest increase. The southern regime has a lower index. The CEENMS also started from a lower level, but now have nearly reached the level of the EU-15. The development of the overall globalization index in the socialdemocratic, conservative and liberal regimes are very similar. The catch-up process in the southern countries is also stronger, whereas the CEENMS have a remarkably lower index value throughout.

\subsection{The Tax Burden on Capital Income, Labor Income and Consumption}


Different types of tax rates are used in empirical studies. Statutory tax rates (STRs) on capital or corporate income are directly derived from the tax code. However, they do not account for the tax base. Effective marginal and average tax rates likewise use data from the tax code. They measure the tax burden on a hypothetical investment project based on actual tax law (Devereux and Griffith, 1998; Devereux et al., 2002). A third widely used measure is average effective tax rates (AETRs), calculated by dividing the total tax revenue from capital or corporate income, labor income or consumption by the pre-tax income or consumption (Mendoza et al., 1994; Carey and Rabesona, 2002). Eurostat is adapting this method to calculate implicit tax rates (ITRs). ${ }^{2}$ These tax rates are especially suitable for exploring changes in the tax burden. Therefore we base our analysis on the ITRs.

For the ITRs Eurostat data is employed. The data source for the period starting in 1990 is the Eurostat online database. These data are extended backwards to 1970 or 1980 with the growth rates of the ITRs calculated by the EC (2000). The data on the ITR on capital for Romania, Bulgaria and Slovenia are extended with our own calculations, based on the method used by the EC. ${ }^{3}$ Thus, the data for nine countries ${ }^{4}$ reaches back until 1970, for six countries ${ }^{5}$ until 1980, and for most CEENMS until 1995.

Figures 3-5 show the development of the unweighted average of the ITR on capital income, labor income and on consumption.

[Figure 3]

Although STRs on capital decreased (Devereux et al., 2002), the ITR on capital stayed rather stable, due to the broadening of the tax base. The level of capital taxation is

${ }^{2}$ Eurostat's terminology for AETR is ITR. We will further use this terminology.

${ }^{3}$ The ITR on capital for Romania during 1998-2004, for Bulgaria for 1999 and 20022007, for Slovenia during 1995-1999 are calculated as (capital taxes as share of GDP * GDP) / (gross operating surplus - consumption of fixed capital) using data in Eurostat about the structure of taxes by function as share of GDP.

${ }^{4}$ Belgium, Germany, Denmark, France, Ireland, Italy, Luxemburg, the Netherlands, United Kingdom

${ }^{5}$ Austria, Spain, Finland, Greece Portugal, Sweden 
much lower in the CEENMS compared to Western Europe. The ITR on capital has fallen in the liberal regimes (apart from a recent increase), while it has been rising in the socialdemocratic regimes in particular since the mid 1990s. In the conservative regimes the ITR on capital slightly decreased over the whole period 1980-2007. In the southern regimes the ITR on capital had been considerably lower than in the other welfare state regimes until the beginning of the 1990s, but since then it has increased and now corresponds to that of the liberal regime. Given that the process of globalization has intensified in all these regimes, the differences in the developments in the ITRs are remarkable. There are important differences in the trends in the CEENMS as well. The ITR on capital fell strongly in Slovakia; maintained its initial levels in the Baltics despite an early period of decline, and remained quite stable in the other countries. It is interesting that this stability took place in the CEENMS in an era of major globalization.

[Figure 4]

The ITRs on labor are on average higher than those on capital. The difference between the ITR on capital and labor is much higher in the CEENMS. With the exception of the liberal regimes there is a converging trend in the ITRs on labor in the social-democratic, conservative and southern regimes. This goes along with the increase in globalization. Countries in the social-democratic welfare regimes have the highest ITR on labor. In the countries of both the post-communist European and the Baltic regimes the ITR on labor has been decreasing, albeit more strongly in the latter. All three Baltic States introduced flat tax very early in 1994-95, followed by Slovakia and Romania.

[Figure 5]

The social-democratic regimes have the highest ITR on consumption, and the southern regimes have the lowest ITR in the West, although it has been constantly increasing since 1980. The level of the ITR on consumption in the post-communist European regimes 
corresponds to those of the conservative and liberal regimes, whereas the rate in the Baltics is slightly lower.

\subsection{Social Expenditures}

In order to capture the effect of globalization on the composition of spending with regard to public consumption goods, we focus on social expenditures, rather than intermediate spending categories like education or health, which are not only public consumption goods but also public inputs for the firms. We prefer normalizing social expenditures by total expenditures to normalizing by GDP in order to capture the effects on the distribution of spending (Kaufman and Segura-Ubiergo, 2001; Leibrecht et al., 2011).

Eurostat's classification of the functions of government (COFOG) database provides data on 'social protection' expenditure on sickness and disability, old age, family and children, survivors, unemployment and housing. However the COFOG data as a ratio to total expenditures in Eurostat is available only since 1990. The time series are extended with data from OECD National Accounts Vol. II.

Figure 6 shows the development of the unweighted average of social expenditure as a ratio to total expenditures (socexp).

[Figure 6]

In the EU15 the social-democratic regimes have the highest share of social expenditures, which has been slightly rising since 1995. The trends in social spending indicate convergence among the social-democratic, conservative, and southern regimes towards similar levels as a share in total spending. It seems like globalization has not led to welfare state retrenchment in these regimes; however in order to pin down the effects of globalization, we need an econometric analysis after controlling for other explanatory factors. In the liberal regimes, the share of social expenditures increased until 1994 but since then has 
decreased. In the CEENMS the share of social expenditures has been declining in both regimes, but the Baltics have a much lower share.

\section{Estimation Methodology}

We introduce a broad set of control variables common to both the spending and tax equations based on the previous empirical literature (e.g. Adam and Kammas, 2007; Bretschger and Hettich, 2002; Dreher et al., 2008a and 2008b; Leibrecht et al., 2011; Swank and Steinmo, 2002; Gemmel et al., 2008; Sanz and Velazquez, 2007; Winner, 2005): the ratio of total expenditures of general government to GDP (expenditure), which captures the size of the public sector; government consolidated gross debt as a percentage of GDP (debt), which reflects the budget constraint as well as alternative means of finance; the fraction of population older than 65 years as a share of total population (oldage), which captures the effect of the increasing proportion of the dependent population on the tax and expenditure system; the growth rate of real GDP (growth), which aims to capture cyclical effects; inflation measured as the change in the GDP deflator (inflation) ${ }^{6}$; ; government party (govparty), which reflects the composition of the government's cabinet and ranges from 1 to 5 ( 1 = hegemony of right-wing (and centre) parties, 5 = hegemony of social-democratic and other left parties); a country's relative size - the proportion of a country's GDP to the average sample GDP- (size), which is included in order to avoid a possible small country bias in the coefficient of the globalization indices, as smaller countries are typically more open than larger. Table A.1 in the appendix contain information on the variables and the databases.

${ }^{6}$ In our sample period, there is only one year of hyperinflation (147\%) in Romania in 1997, where data for the ITR on capital starts in 1998. For all the other variables in Romania the data starts in 1999 or later; thus there are no hyperinflation years. For other countries, which have experienced hyperinflation (Bulgaria, and the Baltic states), our estimation period for which data for the dependent variables are available does not include any hyperinflation years. The results are robust to the exclusion of 1998 in Romania for the estimations for the ITR on capital regarding the effects of inflation as well as globalization indices. 
We explore the effect of globalization on social expenditures and the various ITRs by using the following baseline model:

$$
B_{j i t}=\alpha_{j i}+\omega_{j t}+\gamma_{\mathrm{j}} \mathrm{B}_{\mathrm{ji}(\mathrm{t}-1)}+\beta_{j g} G_{i t-1}+\beta_{j c} C_{i t-1}+\varepsilon_{j i t}
$$

where $B j=$ social expenditures as a ratio to total expenditures, the ITRs on capital income, labor income, or consumption, and the subscript $\mathrm{j}$ indicates different regressions with different dependent variables. ${ }^{7}$ We estimate separate equations for Western Europe and CEENMS to allow for country-group-specific coefficients. Thus, the country index, i, ranges from 1 to 15 for Western Europe and from 1 to 10 for the CEENMS; t is the time index ranging from 1970-2007 for the ITRs in Western Europe, 1980-2007 for social spending in Western Europe, and 1995-2007 in the CEENMS for all equations. $\alpha_{j i}$ are country fixed effects, $\omega_{j t}$ are time fixed effects. $\varepsilon_{j i t}$ is the error term. ${ }^{8} G_{i t-1}$ is the globalization index (KOFecon or KOFglobal), and $C_{i t-1}$ is the matrix of control variables, all of which except for government cabinet gravity enter into the equations with a one year lag.

The aim of using lagged explanatory variables is to incorporate the time lags in the decision process as well as to address the problems of endogeneity. ${ }^{9}$ Due to the low number of countries (cross-sections), a GMM-estimation to cope with endogeneity is not possible; therefore we follow Wooldridge’s (2002:301) suggestion to use lagged explanatory variables as a second best approach. The alternative of instrumental variables approach is also not

${ }^{7}$ Our dependent variables as well as the explanatory variables are all ratios or growth rates, and panel unit roots reject the presence of unit roots; therefore we proceed with estimating the models in levels rather than differences.

${ }^{8}$ Following Leibrecht et al (2011) estimations are made using Schaffer's xtivreg2 Stata command (Schaffer, 2010), which allows for standard errors, which are fully robust with respect to serial correlation and general heteroscedasticity, as the variance-covariance-matrix of the error term is calculated using the approach developed by Newey and West (1987). The alternative cluster-robust standard errors need a large number of clusters for reliable inference (Nichols and Schaffer, 2007).

${ }^{9}$ The government cabinet gravity is not lagged, since there is no endogeneity problem involved in this case. 
reliable due to the absence of variables, which are highly correlated with globalization and the control variables but exogenous to taxes and spending.

In order to account for path dependency a dynamic model using the Least Square Dummy Variable (LSDV) estimator with lagged dependent variable is estimated. Again due to the low number of countries, the Arellano and Bond (1991) estimator is not appropriate (also see Potrafke, 2009). However, in the presence of fixed country effects, the results are biased for short time series (Nickell, 1981). For the EU15, where the time period is 1970-2007, this poses only minor problems. Judson and Owen (1999) shows that the LSDV estimator with lagged dependent variable performs well with unbalanced panels. ${ }^{10}$ However, for the CEENMS the time period is 1995-2007, thus much shorter; therefore the results for the CEENMS must be interpreted as indicative.

The total expenditure as a control variable also captures the dynamic effects of path dependency and introduces a common exogenous constraint on both the revenue and the social expenditure side.

A note about the bounded nature of the share of social expenditures and the ITRs is in place here: OLS assumes that the dependent variables are unbounded; however, this does not pose a major problem in our case, since our dependent variables are far from the bounds $(0$

${ }^{10}$ We nevertheless estimated the Arellano and Bover (1995)-Blundell and Bond (1998), two-step estimation using Windmeijer's finite-sample correction and orthogonal deviations. However, the Hansen-J test indicates overfitting (p-value of 1 ) and there is second-order autocorrelation; thus minimum requirements for reliable estimates are not met. Given the low number of countries in our sample, as Roodman (2009) suggests, Arellano and Bover-Blundell and Bond estimator may face the problem of an overabundance of instruments, which inflates the p-values of the Hansen-J test results. We also estimated the bias-corrected LSDV estimator developed by Bruno (2005) with the Blundell and Bond as the initial estimator, however, to derive the bias-correction term Bruno estimator needs a consistent first round estimator, and thus also relies on Blundell-Bond estimates, which are not appropriate in our case as discussed above. Furthermore, Bruno estimator needs strictly exogenous variables, and is not applicable in the presence of even only weakly exogenous regressors. 
and 100). Moreover, Winner (2005) shows that logistic transformation does not change the results; but the interpretation of coefficients becomes complicated.

Next we test for the heterogeneity of the effects of globalization in different welfare state regimes by extending Equation (1) as follows:

$$
\begin{aligned}
& B_{j i t}=\alpha_{j i}+\omega_{j t}++\gamma_{\mathrm{j}} \mathrm{B}_{\mathrm{ji}(\mathrm{t}-1)}+\beta_{\mathrm{jg}} \mathrm{G}_{\mathrm{i}(\mathrm{t}-1)}+\sum_{k=1}^{n} \beta_{j g k} D_{k i t} G_{i t-1}+\beta_{j c} C_{i t-1}+ \\
& \sum_{k=1}^{n-1} \rho_{k} D_{k} T+\varepsilon_{j i t}
\end{aligned}
$$

where $D_{k}$ is a dummy variable representing the different welfare regimes. In Western Europe $D_{1}, D_{2}$, and $D_{3}$ stand for the social-democratic, southern and liberal regimes respectively. The conservative regime is the base regime. In the CEENMS $D_{1}$ stands for the Baltic regimes, and the post-communist European regime is the base regime. We do not add the regime intercept dummies, since we already have country specific fixed effects. Due to limitations of degrees of freedom, we have interaction dummies only for the globalization indices; thus the coefficients of the control variables remain the same across the regimes. However, a welfare regime specific trend is also included in order to account for regime specific shocks, which are not captured by the control variables or the common time dummies as in Leibrecht et al (2011). Due to the presence of time dummies, one welfare specific trend is excluded.

\section{Estimation Results}

\subsection{EU15}

Table 1 shows the results for the basic specification for the EU15. In all specifications, the lagged dependent variables are significant with a positive sign, verifying the importance of path dependency in spending and taxes. The time dummies are jointly significant in all specifications except the specification with KOFglobal in the estimation of ITR on labor (Column (5)). We keep the time dummies as well as other explanatory variables even if they are insignificant, and discuss the robustness of the results where relevant. The 
effects of the globalization indices are robust to the exclusion of the other explanatory variables.

In the EU15 an increase of economic globalization (KOFecon) has a positive effect on social expenditures as a ratio to total expenditures, whereas overall globalization (KOFglobal) is insignificant. Countries seem to be compensating for increasing risk caused by economic globalization by augmenting social expenditures. This compensation effect is in line with Gemmel et al. (2008), Hicks and Swank (1992), Bretschger and Hettich (2002), Dreher et al. (2008b) and Leibrecht et al. (2011), although the measure of globalization may differ among the studies. However, Dreher (2006a), Sanz and Velazquez (2007), Dreher et al. (2008a), and Potrafke (2009) find no significant effect of globalization on social expenditures, but the results are not directly comparable, since they are very sensitive to country coverage, as we will show below.

[Table 1]

Regarding the effect of globalization on taxation, there is no significant effect on the ITR on capital (Columns (3) and (4)). This is in line with Dreher et al. (2008a), Swank (2006) and Swank and Steinmo (2002). However, Winner (2005) finds a negative effect of globalization on the ITR on capital income, while Dreher (2006a) finds a positive effect. Adam and Kammas (2007), Bretschger and Hettich (2002), as well as Bretschger (2010) likewise find a negative effect of globalization using the ITRs on corporate income as dependent variables. However, their measures of globalization are limited to trade volume, and different indices to measure legal restrictions. The results are furthermore sensitive to the country sample. 
Columns (5) and (6) show the results for the ITR on labor. Economic globalization index (KOFecon) has a positive effect. ${ }^{11}$ While there is no effect on taxes on capital, the tax burden on the immobile factor is rising due to globalization. This positive effect is in line with Dreher et al. (2008a), Adam and Kammas (2007) and Winner (2005). Likewise, Bretschger and Hettich (2002), Garret and Mitchell (2001) and Schwarz (2007) find a shift of the tax burden from capital to labor, when estimating the ratio of taxes on capital to labor. Nevertheless, Dreher (2006a) finds no effect and Swank and Steinmo (2002) find a negative effect on taxes on labor; however the latter study uses only the capital controls index as the measure of globalization.

Globalization has no significant effect on the ITR on consumption (Columns 7-8).

Next, Table 2 reports the results for the four welfare state regimes in Western Europe. ${ }^{12}$ The lagged dependent variables as well as the common time fixed effects are jointly significant in all specifications. The F-tests on joint significance of the coefficients (base group of the conservative regime plus the interaction dummy for the other three regimes) are reported at the end of each specification.

\section{[Table 2]}

There are significant differences between the four welfare state regimes. Overall globalization has a positive effect on social expenditures in the conservative regime, while in the liberal regime globalization is leading to a decline in social expenditures (Column 1). In the social-democratic and southern regimes social expenditures are not affected by globalization. Interestingly economic globalization has no statistically significant effect in any of the regimes as opposed to the findings in the aggregate estimation. This shows that it is mostly the social and political integration that shape the demands of the citizens in the case

${ }^{11}$ In this specification, when the time effects, which are jointly insignificant, are excluded, KOFglobal is also statistically significant and positive.

${ }^{12}$ As a robustness check, we also exclude the Netherlands from the sample due to its arguably hybrid character as discussed in Section 2; the results are robust. 
of the conservative regimes; this may be linked to aspirations driven by the social-democratic models in Europe. Globalization is leading to a convergence of the conservative regime with lower social spending level towards the social-democratic regime, as suggested in the political economy literature (e.g. Kautto and Kvist, 2002; Adelantado and Cuevas, 2006; Achterberg and Yerkes, 2009; Huber and Stephens, 2001). There is no general race-to-thebottom in terms of welfare regimes in the case of the conservative regimes. Meinhard and Potrafke (2012) also find that social globalization has a positive effect on aggregate government spending, while economic globalization has no effect in a larger sample of 186 countries as well as the OECD countries, and interpret their finding as evidence of a catch-up effect as more people have been globally interconnected and observed government sector in other countries.

The negative effect of overall globalization in the liberal regimes however indicates that catching-up convergence is specific to the conservative regimes. In the liberal regime the negative effect of overall globalization without any significant effect of economic globalization may be an indicator that social spending cuts were motivated by a discourse about increasing competitive pressures in a period of rapid political integration across Europe although the economic pressures themselves were not significant, and these countries had a higher exposure to economic globalization compared to other regimes already back in the 1970s.

The lack of a significant effect in the southern as well as social-democratic regimes indicates that in these countries domestic factors and path dependency are more important than international effects in driving social expenditures.

Our results, based on a different database with longer time series and a dynamic rather than a static model are similar to Leibrecht et al. (2011) in the case of the conservative 
regime, but they do not find the negative effect in the liberal regime, while they find some negative effect in the case of the social-democratic regime. ${ }^{13}$

Regarding the effect of globalization on taxes, the results are reported in columns (3) to (8). In the social-democratic regime, rising globalization is leading to decreasing taxes on capital, whereas in the other regimes there is no significant effect. It can be argued that in the social-democratic regime, where capital taxes have been significantly higher, globalization is leading to a downward convergence.

Globalization leads to a rise in taxes on labor in the conservative, social-democratic, and liberal regimes, although in the latter two only KOFecon is significant. There is no significant effect in the southern regime. Even though labor taxes in the southern regime have been rising more strongly than in the other regimes, apparently this rise is not caused by globalization, but by domestic factors. The economic significance of the effect is largest in the social-democratic regime. ${ }^{14}$

Finally, economic globalization has a negative effect on the ITR on consumption in the conservative and social-democratic regimes.

\subsection{CEENMS}

Table 3 reports the results for the CEENMS pooled together. In all specifications, the lagged dependent variables are significant with a positive sign.

[Table 3]

13 Leibrecht et al (2011) use COFOG database which starts only in 1990s. Our database for the Western European countries dates back to 1980s for some countries.

${ }^{14}$ In the social-democratic regime globalization has led to a $2.9 \%$-point increase in the ITR on labor, and 1.5\%-point and 1.1\%-point increases in the liberal and conservative regimes respectively. 
In the CEENMS there is no effect of globalization on social expenditures as opposed to Western Europe. ${ }^{15}$ Interestingly, economic globalization is exerting an upward pressure on the ITR on capital ${ }^{16}$, whereas there is no statistically significant effect of globalization on the ITR on labor. There is a statistically significant negative effect of both globalization indices on the ITR on consumption. Leibrecht et al. (2011) find a negative effect of globalization on social expenditures; however their model is static, and their estimation period is 2000-2006 for most of the CEENMS, whereas our data cover the period of 1995-2007; i.e. also the earlier period of catching-up with European welfare standards.

Next, we repeat the estimations for two different regimes in the CEENMS, i.e. a postcommunist European type, and a Baltic type. Table 4 reports the results. The lagged dependent variables are again significant.

[Table 4]

Our results indicate differences in the effects of globalization on taxes and spending in the Baltic countries and the other CEENMS, and provide some support to the arguments in Fenger (2007) and Bohle and Greskovits (2007) about different welfare regimes in the CEENMS. In the post-communist European regime the effect of globalization (KOFglobal) on social expenditures is significant and positive, but in the Baltic countries there is a significant negative effect of both indices. When the regime specific differences are controlled for, there is no significant effect of globalization (both indices) on the ITR on capital in any of the regimes. In the post-communist European type we find a negative effect

${ }^{15}$ However, when the jointly insignificant time dummies are excluded, we find a positive effect of KOFecon on social expenditures. This seemingly non-robust finding will be discussed further below with respect to the differences between welfare regimes.

${ }^{16}$ When the jointly insignificant time dummies are excluded, there is no statistically significant effect of globalization on taxes on capital. 
of economic globalization on the ITRs on consumption reflecting the effects of flat tax reforms. $^{17}$

\section{Conclusion}

Globalization has significant effects on the government budgets; however, the responses of the states are shaped by the economic and political institutions in different welfare regimes.

In Western Europe globalization leads to an increase in social expenditures. However, these expenditures are financed by taxes on labor. Overall on the expenditure side the compensation hypothesis is verified whereas on the revenue side efficiency pressures prevail. These two hypotheses are complementary rather than competing.

This outcome is, however, dominated by the trends in the conservative regime. There is evidence of catching-up convergence in the conservative regime towards the socialdemocratic regime regarding social expenditures in response to political and social globalization. This can be interpreted as further decommodification in the conservative regimes towards the higher levels in the social-democratic regimes; however this is financed by higher taxes on labor. In the social-democratic regime, there is no evidence of welfare retrenchment in response to globalization, but the continuity of social spending is maintained by decreasing tax burden on capital and increasing taxes on labor; thus efficiency effects prevail on the revenue side. Further increases in labor tax can be evaluated as part of the social-democratic consensus to preserve the welfare regime without increasing the burden on capital. The decline in the ITR on consumption, which is a regressive tax, offsets part of the increase in the tax burden on labor in the conservative and social-democratic regimes. In the liberal regime, the ITR on labor increases as a consequence of globalization, whereas social

${ }^{17}$ When the jointly insignificant time effects are excluded, there is significant positive effect of KOFecon on the ITR on capital in the Baltic countries. The low levels of the taxes in the Baltics might have helped to decrease informalization, and increase capital tax revenues as Duman (2010) suggests. 
spending decreases; thus there is evidence of efficiency effects of globalization on both the revenue and expenditure sides. In the southern regime globalization does not have any significant effects on the distribution of taxes or social spending, which is puzzling given the presence of overall upward convergence in social spending and taxes in these countries. Our results indicate that this convergence has been mainly due to internal factors rather than economic, political, or social globalization.

In the CEENMS, there are also important differences between the two regimes: Globalization leads to compensating effects on social spending and catching-up convergence only in the post-communist European regime, but negative efficiency effects prevail in the Baltics. The post-communist European regime resembles the Western conservative regime in its compensating response to globalization; however the effects on taxes are rather different. In the post-communist European type we find a negative effect of globalization on the ITRs on consumption, and no significant effect taxes on labor or capital. In the case of the Baltics, where flat tax reforms took place earlier, we do not observe any robust significant effect of globalization on taxes. .

There is no general race-to-the-bottom in terms of social spending in the case of the conservative regimes or some CEENMS. However, the negative effects of globalization on social spending in the liberal regimes in Western Europe and the Baltic States with already low levels of social spending indicate that globalization may enhance the divergences between the liberal regimes and other member states. Furthermore, globalization leads to an increase in the tax burden on labor or a decline in the tax burden on capital in Western Europe. In order to shed light on the exact institutional and political processes that have generated these outcomes, further qualitative research is required about the alliances and framing of the discourses. 


\section{References}

Achterberg P, Yerkes M 2009. “One welfare state emerging? Convergence versus divergence in 16 western countries.” Journal of Comparative Social Welfare, 25, 189-201

Adam A, Kammas P 2007. “Tax Policy in a Globalized World: Is It Politics After All?” Public Choice, 133, 321-341.

Adelantado J, Cuevas E.C 2006. “Globalization and the Welfare State: The Same Strategies for Similar Problems?” Journal of European Social Policy 16, 374-386.

Arts W, Gelissen J 2002. "Three worlds of welfare capitalism or more? A state of-the-art report”, Journal of European Social Policy 12(2), 137-158.

Bellak C, Leibrecht M 2009. “Do Low Corporate Income Tax Rates Attract FDI? Evidence From Central- and East European Countries.” Applied Economics 41, 2691-2703.

Bohle D, Greskovits B 2007. “Neoliberalism Embedded Neoliberalism and Neocorporatism: Towards Transnational Capitalism in Central-Eastern Europe.” West European Politics 30, 443-366.

Bonoli G 1997. “Classifying Welfare States: A Two-Dimension Approach.” Journal of Social Policy 26, 351-172.

Bonoli G 2007. Time matters: Postindustrialization, new social risks, and welfare state adaptation in advanced industrial democracies. Comparative Political Studies 40(5), 495-520.

Brady D, Beckfield J, Seeleib-Kaiser M 2005. "Economic Globalisation and the Welfare State in Affluent Democracies, 1975-2001.” American Sociological Review 70, 921948.

Bretschger L 2010. “Taxes, Mobile Capital, and Economic Dynamics in a Globalizing World.” Journal of Macroeconomics 32, 594-605.

Bretschger L, Hettich, F 2002. “Globalisation, Capital Mobility and Tax Competition: Theory and Evidence for OECD Countries.” European Journal of Political Economy 18, 695716.

Brook A, Leibfritz W 2005. "Slovakia's Introduction of a Flat Tax as Part of Wider Economic Reforms.” Working Paper, OECD Economics Department.

Bruno G.S.F. 2005. "Approximating the bias of the LSDV estimator for Dynamic Unbalanced Panel Data Models”. Economics Letters 87, 361-366.

Bucovetsky S 1991. “Asymmetric Tax Competition.” Journal of Urban Economics 30, 167181. 
Campbell, J.L 2005. "Fiscal Sociology in an Age of Globalization: Comparing Tax Regimes in Advanced Capitalist Countries.” In The Economic Sociology of Capitalism, eds Nee V., Swedberg R. Princeton University Press.

Carey, D, Rabesona J 2002. “Tax Ratios on Labour and Capital Income and on Consumption.” OECD Economic Studies 35.

Clasen J,. Van Oorschot W 2002. “Changing principles in European social security”, European Journal of Social Security 4(2), 89-116.

Davies R.B, Egger H, Egger P 2003. Tax Competition for International Producers and the Mode of Foreign Market Entry, WP 2006-19, University of Oregon.

Davies R.B, Voget J 2008. Tax Competition in an Expanding European Union, WP 0830, Oxford University Centre for Business Taxation.

Devereux M.P, Griffith R 1998. “The Taxation of Discrete Investment Choices.” Working Paper, Institute for Fiscal Studies, London.

Devereux, M.P, Griffith R, Klemm A 2002. "Corporate Income Tax Reforms and International Tax Competition.” Economic Policy 17, 451-495.

Devereux M.P, Lockwood B, Redoano M 2008. Do Countries Compete over Corporate Tax Rates? Journal of Public Economics 92(5-6), 1210-1235.

Dreher A 2006a. “The Influence of Globalisation in Taxes and Social Policy; An Empirical Analysis for OECD Countries.” European Journal of Political Economy 2, 179-201.

Dreher A 2006b. "Does Globalization Affect Growth? Evidence from a new Index of Globalization.” Applied Economics 38, 1091-1110

Dreher A, Gaston N, Martens P 2008a. Measuring Globalization - Gauging its Consequences, Springer.

Dreher A, Sturm J, Ursprung H.W 2008b. “The Impact of Globalization on the Composition of Government Expenditures: Evidence from Panel Data.” Public Choice 134, 263292.

Duman A 2010. "Flux or Fixed : Tax Reforms, Informal Economy and Foreign Investment in New EU Member States.” WP, Vienna University of Economics and Business, SFB International Tax Coordination, 36.

Esping-Andersen, G 1999. The Social Foundations of Postindustrial Economies. Oxford University Press.

European Commission 2000. Structures of the Taxation Systems in the European Union. Eurostat Statistical Books. 
Fenger M 2007. "Welfare Regimes in Central and Eastern Europe: Incorporating PostCommunist Countries in a Welfare Regime Typology.” Contemporary Issues and Ideas in Social Sciences 3(2), 1-30.

Ferge Z 2001. Globalization and European Welfare States: Challenges and Changes, Palgrave.

Ferrara M 1996. “The Southern Model of Welfare in Social Europe.” Journal of European Social Policy 6, 179-189.

Garrett G, Mitchell D 2001. "Globalization, Government Spending and Taxation in the OECD.” European Journal of Political Research 39, 147-177.

Gemmel N, Kneller R, Sanz I 2008. "Foreign Investment, International Trade and the Size and Structure of Public Expenditures.” European Journal of Political Economy 24, 151171.

Hacker J.S 2004. "Privatizing Risk without Privatizing the Welfare State: The Hidden Politics of Social Policy Retrenchment in the United States.” American Political Science Review 98, 2, 243-260.

Hall, P.A, Soskice D 2001. “An Introduction to Varieties of Capitalism” in eds. Hall, P.A, Soskice D, Varieties of Capitalism: The Institutional Foundations of Comparative Advantage. New York: Oxford University Press.

Hicks A, Swank D 1992. "Politics, Institutions and Welfare Spending in Industrialized Democracies.” American Political Science Review, 86, 658-674.

Huber, E, Stephens J 2001. Development and Crisis of the Welfare State University of Chicago Press.

Johnston A, Kornelakis A, d'Acri C.R 2011. Social partners and the welfare state: Recalibration, privatization or collectivization of social risks? European Journal of Industrial Relations 17, 349-364

Kautto M, Kvist J 2002. "Parallel Trends, Persistent Diversity: Nordic Welfare States in the European and Global Context.” Global Social Policy 2, 189-208.

Keen M,Marchand M 1997. “Fiscal Competition and the Pattern of Public Spending.” Journal of Public Economics 77, 33-53.

Keen M, Kim Y, Varsano R 2008. “The 'flat tax(es)': principles and experience.” International Tax and Public Finance 15, 712-751.

Leibrecht M, Klien M, Onaran Ö 2011. “Globalization, welfare regimes and social protection expenditures in Western and Eastern European countries.” Public Choice 148(3), 569594 
Lelkes O 2000. “A Great Leap Towards Liberalism? The Hungarian Welfare State.” International Journal of Social Welfare 9, 92-102.

Meinhard S., Potrafke N 2012. “The globalization-welfare state nexus reconsidered” Review of International Economics forthcoming.

Mendoza E.G, Razin A, Tesar L.L 1994. "Effective Tax Rates in Macroeconomics CrossCountry Estimates of Tax Rates on Factor Incomes and Consumption.” Journal of Monetary Economics 34, 297-323.

Newey, W. K, West K.D 1987. “A Simple, Positive Semi-Definite, Heteroskedasticity and Autocorrelation Consistent Covariance Matrix.” Econometrica 55, 703-708.

Nichols A, Schaffer M 2007. Cluster Errors in Stata. Paper presented at the 2007 UK Stata Users Group meeting.<http://www.stata.com/meeting/13uk/nichols_crse.pdf>

Nickell, S.J 1981. "Biases in Dynamic Models with Fixed Effects", Econometrica 49, 141726.

Oates W.E 1972. Fiscal federalism. Harcourt Brace Jovanovich.

Onaran Ö 2008. "Jobless Growth in Central and Eastern European Countries: A Country Specific Panel Data Analysis for the Manufacturing Industry.” Eastern European Economics 46(4), 97-122

Onaran, Ö., Bösch, V., Leibrecht, M. 2012. “How does globalization affect the tax burden on labour income, capital income and consumption in different welfare regimes? The case of Western and Eastern EU Member States”, Economic Inquiry, 50(4), 880-904

Orenstein M.A, Haas M.R 2005. Globalization and the Future of the Welfare State. University of Pittsburgh Press.

Overesch M, Rincke J 2008. Tax Competition in Europe 1980-2007: Evidence from Dynamic Panel Data Estimation, WP, CESifo Conference, 26-27 April , Nubich.

Pierson P 1996. The new politics of the welfare state. World Politics 48(2), 143-179.

Pierson P 2001. The New Politics of the Welfare State. Oxford: Oxford University Press.

Pluemper T, Troeger V.E, Winner H 2009. "Why is there no race to the bottom in capital taxation?” International Studies Quarterly 53(3), 761-786.

Potrafke N 2009. "Did Globalization Restrict Partisan Politics? An Empirical Evaluation of Social Expenditures in a Panel of OECD Countries.” Public Choice 140,105-124.

Roodman, D 2009. "How to Do xtabond2: An Introduction to Difference and System GMM in Stata.” Stata Journal 9(1), 86-136.

Rodrik D 1998. "Why Do More Open Economies Have Bigger Governments.” Journal of Political Economy 106, 997-1032. 
Sanz, I, Velazquez F.J 2007. “The Role of Ageing In the Growth of Governments.” European Journal of Political Economy 106, 917-931.

Schaffer M.E 2010. Xtivreg2: Stata Module to Perform Extended IV/2SLS, GMM and AC/HAC, LIML and K-Class Regression for Panel Data Models.<http://ideas.repec.org/c/boc/bocode/s456501.html>

Scharpf, F.W, Schmidt V.A 2000. „Introduction.” In From Vulnerability to Competitiveness, eds Scharpf F.W, Schmidt V.A, Oxford University Press.

Schwarz P 2007. ”Does capital mobility reduce the corporate-labor tax ratio?” Public Choice 130, 363-380.

Standing G 1996. "Social Protection in Central and Eastern Europe: A Tale of Slipping Anchors and Torn Safety Nets.” In Welfare States in Transition, ed. G. EspingAndersen. Sage.

Streeck W, Thelen K 2005. “ Introduction: Institutional Change in Advanced Political Economies”in eds. Streeck W, Thelen K, Beyond Continuity: Institutional Change in Advanced Political Economies. Oxford University Press.

Swank D 2002. Global Capital, Political Institutions, and Policy Change in Developed Welfare States. Cambridge University Press.

Swank D 2006. “Tax Policy in an Era of Internationalization, Expanding the Spread of Neoliberalism.” International Organization 60, 847-882.

Swank D, Steinmo S 2002. “The New Political Economy of Taxation in Advanced Capitalist Democracies,” American Journal of Political Science 46, 642-55.

Taylor-Gooby, P 2004. “New Risks and Social Change” In ed. P. Taylor-Gooby, New Risks, New Welfare. The Transformation of the European Welfare State, Oxford: Oxford University Press

Trampusch C 2007. "Industrial relations as a source of social policy: A typology of the institutional conditions for industrial agreements on social benefits“. Social Policy and Administration 41(3), 251-270.

Winner H 2005. “Has Tax Competition Emerged in OECD Countries? Evidence from Panel Data.” International Tax and Public Finance 12, 667-687.

Wooldridge J 2002. Econometric Analysis of Cross Section and Panel Data, MIT Press.

Yerkes M 2011. Transforming the Dutch welfare state: Social risks and corporatist reform, Bristol: Policy Press.

Zodrow GR, Mieszkowski P 1986. "Pigou, Tiebout, Property Taxation, and the Underprovision of Local Public Goods.” Journal of Urban Economics 19, 356-370. 
Figure 1: KOF - Economic globalisation grouped by welfare regimes; 1970-2007

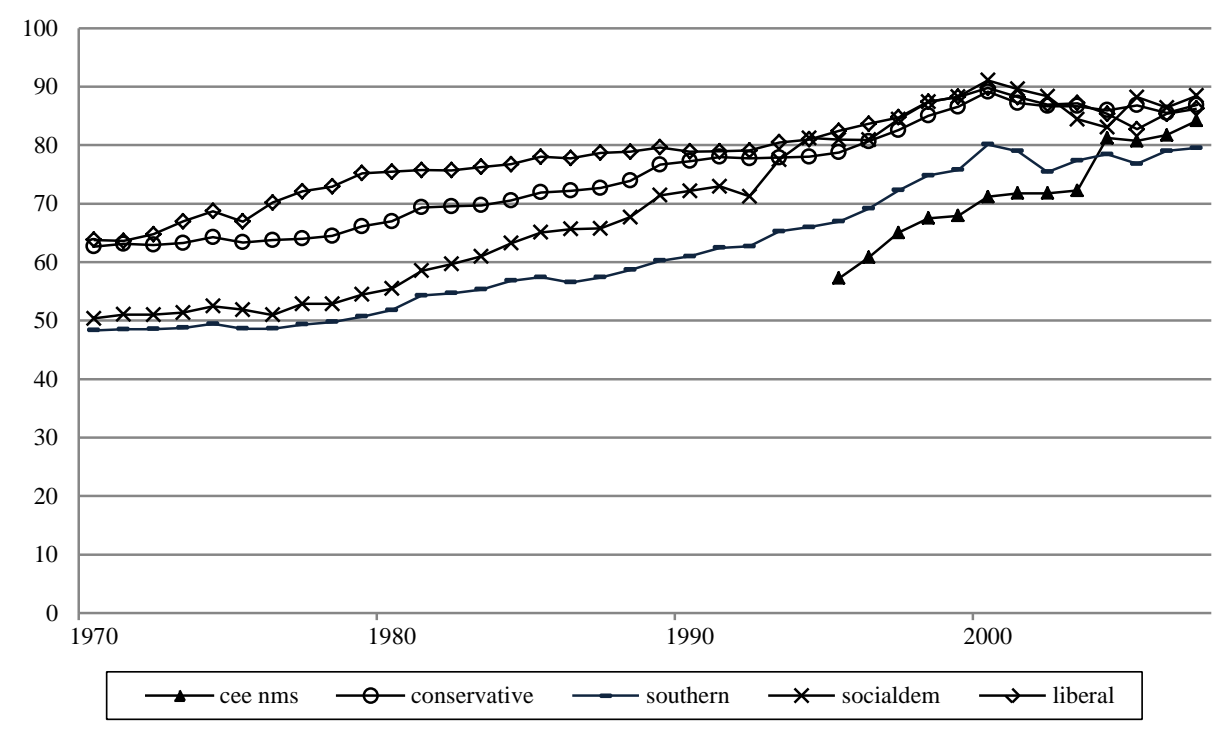

Figure 2: KOF Globalisation index grouped by welfare state regime; 1970-2007

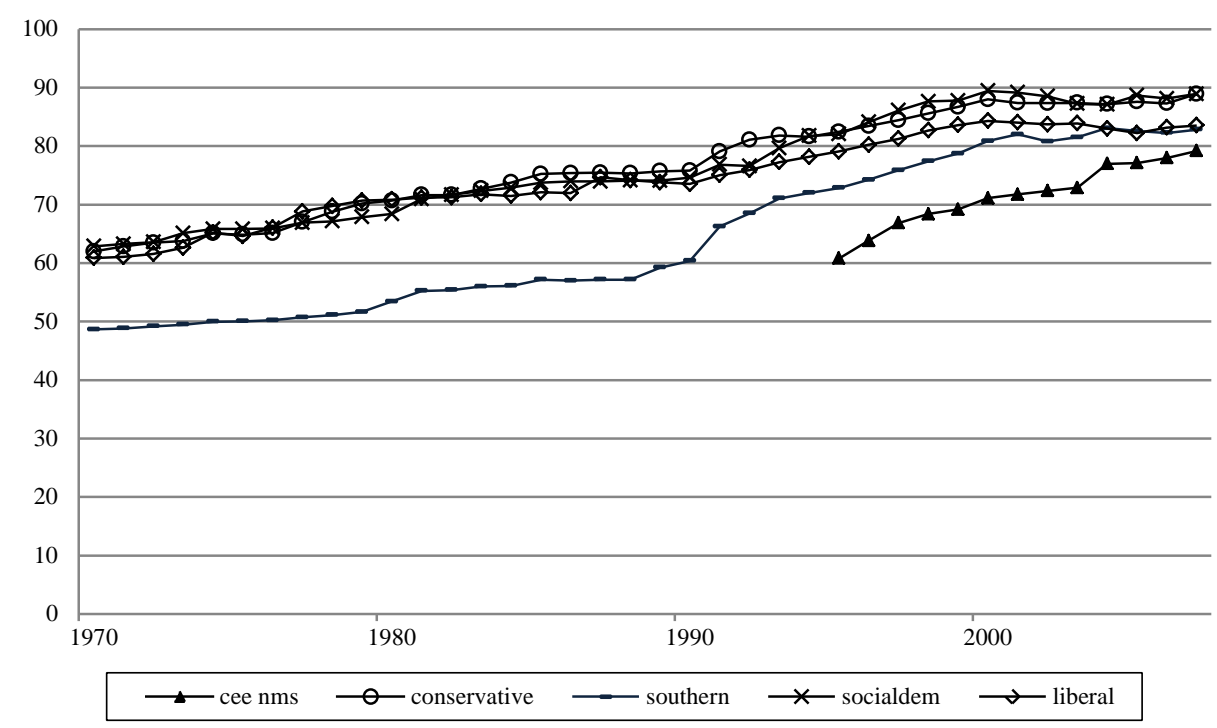


Figure 3. Implicit tax rate on capital income in the EU grouped by welfare state regime $1970-2007$

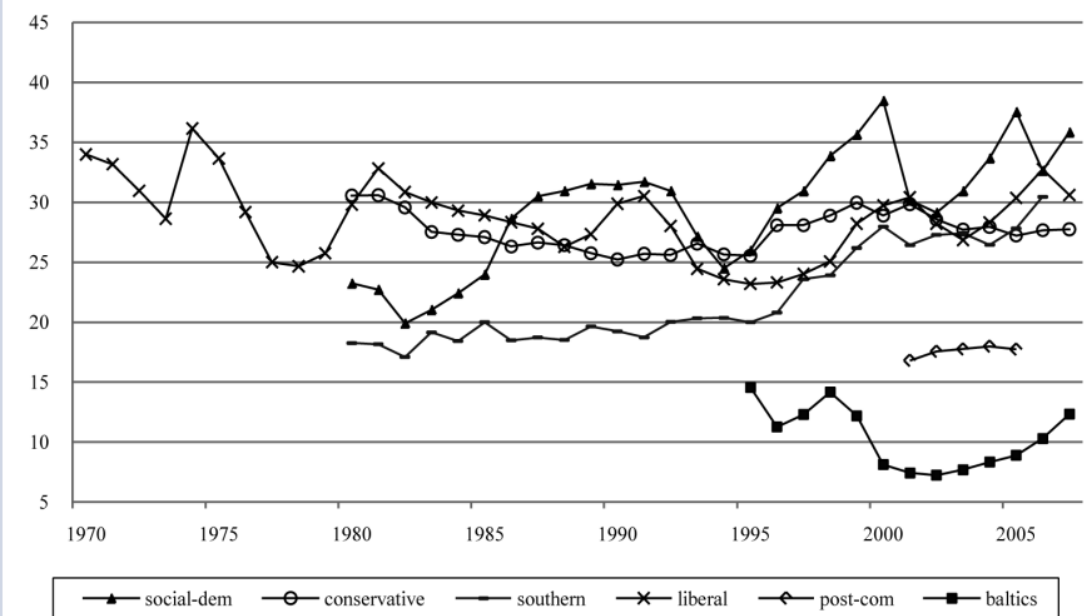

Figure 5. Implicit tax rate on consumption in the EU27 grouped by welfare state regime 1970-2007

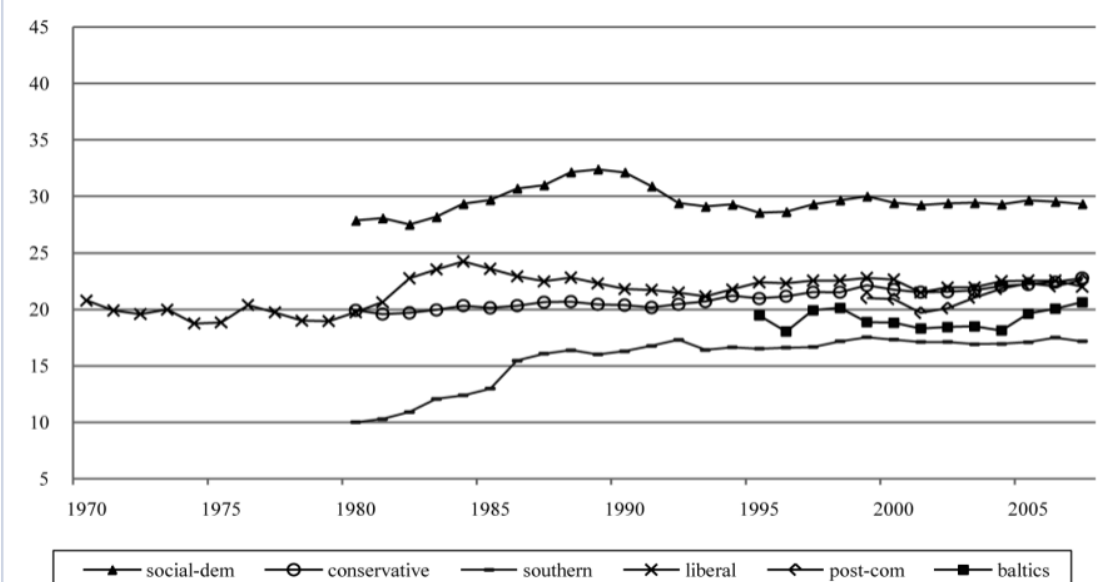

Figure 4. Implicit tax rate on labor income in the EU27 grouped by welfare state regime 1970-2007.

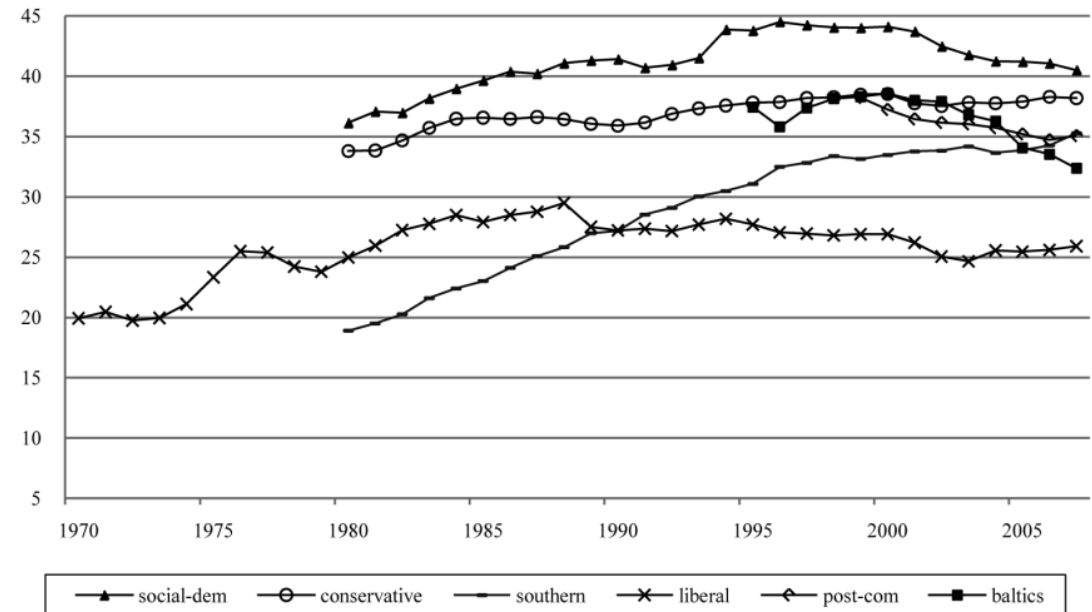

Figure 6. Social protection expenditures as a share of total expenditures grouped by welfare state regime $1990-2007$.

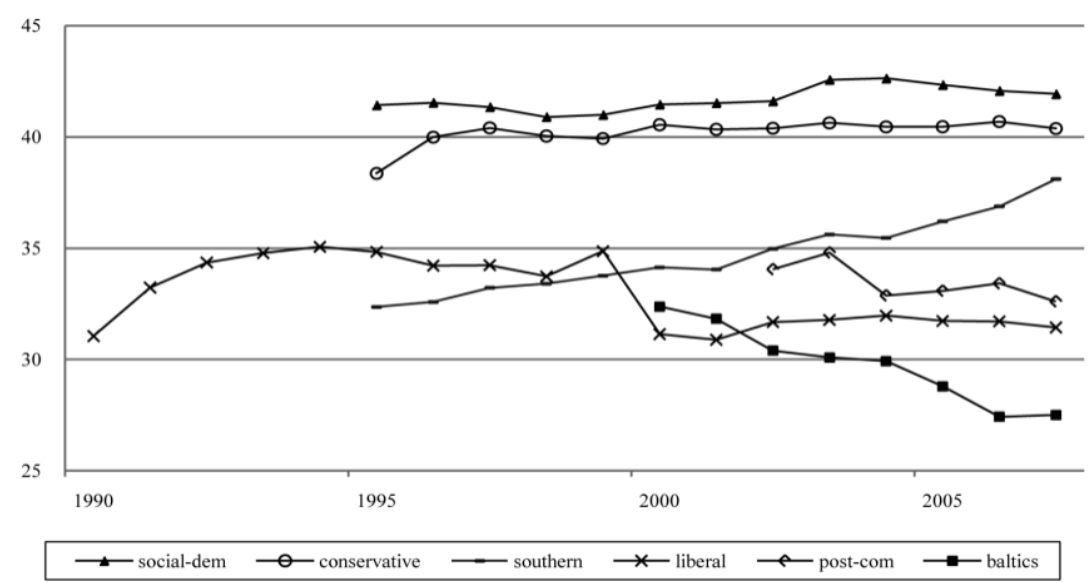

Note: Due to shorter time series for some countries, the aggregation for the regimes start only at a common year, as the aggregation of the unbalanced data for a regime could impose a misleading change in the trend. For the post-communist European regime the aggregation for the ITR on capital income includes only the years 2001-2005, the aggregation for the ITR on labor income and consumption includes the years 1999-2007. For the social protection expenditures the aggregation for the liberal regime includes only the years 1990-2007, for the social-democratic regime, the conservative regime and the southern regime the years 1995-2007, for the post-communist European regime 2002-2007 and the Baltic regime 2000-2007.

Data Source: Eurostat, European Commission (2000), OECD National Accounts Vol. II 
Table 1. Estimation results for the EU15, 1970 - 2007*

\begin{tabular}{|c|c|c|c|c|c|c|c|c|}
\hline & (1) & $(2)$ & (3) & (4) & (5) & (6) & (7) & (8) \\
\hline & socexp & socexp & itr_cap & itr_cap & itr_lab & itr_lab & itr_con & itr_con \\
\hline & $b / p$ & $b / p$ & $\mathrm{~b} / \mathrm{p}$ & $b / p$ & $b / p$ & $b / p$ & $b / p$ & $b / p$ \\
\hline \multirow[t]{2}{*}{ KOFglobal(t-1) } & 0.012 & & -0.043 & & 0.030 & & -0.018 & \\
\hline & $(0.708)$ & & $(0.443)$ & & $(0.172)$ & & $(0.194)$ & \\
\hline \multirow[t]{2}{*}{ KOFecon(t-1) } & & $0.044^{* *}$ & & 0.038 & & $0.032 * *$ & & -0.010 \\
\hline & & $(0.037)$ & & $(0.515)$ & & $(0.044)$ & & $(0.336)$ \\
\hline \multirow[t]{2}{*}{$\operatorname{size}(t-1)$} & 0.000 & -0.021 & $1.042^{* *}$ & $1.050^{* *}$ & 0.057 & 0.127 & 0.035 & 0.002 \\
\hline & -1000 & $(0.938)$ & $(0.014)$ & $(0.016)$ & $(0.674)$ & $(0.313)$ & (0.697) & $(0.978)$ \\
\hline \multirow[t]{2}{*}{ growth(t-1) } & $-0.194 * * *$ & $-0.205^{* * *}$ & 0.163 & 0.147 & -0.002 & -0.013 & 0.039 & 0.043 \\
\hline & $(0.000)$ & $(0.000)$ & $(0.161)$ & $(0.217)$ & $(0.955)$ & $(0.689)$ & $(0.153)$ & $(0.115)$ \\
\hline \multirow[t]{2}{*}{ inflation(t-1) } & -0.036 & -0.044 & -0.059 & -0.056 & 0.034 & 0.027 & 0.013 & 0.017 \\
\hline & $(0.409)$ & $(0.327)$ & $(0.508)$ & $(0.502)$ & $(0.106)$ & $(0.211)$ & $(0.512)$ & $(0.411)$ \\
\hline \multirow[t]{2}{*}{ expenditure(t-1) } & $0.089 * * *$ & $0.089 * * *$ & 0.014 & -0.008 & $0.099 * * *$ & $0.092 * * *$ & 0.010 & 0.011 \\
\hline & $(0.008)$ & $(0.007)$ & $(0.820)$ & $(0.897)$ & $(0.000)$ & $(0.000)$ & $(0.475)$ & $(0.444)$ \\
\hline \multirow[t]{2}{*}{$\operatorname{debt}(t-1)$} & -0.004 & -0.006 & 0.001 & -0.003 & 0.009 & $0.011^{* *}$ & -0.006 & $-0.007^{*}$ \\
\hline & $(0.641)$ & $(0.487)$ & $(0.930)$ & $(0.803)$ & $(0.103)$ & $(0.042)$ & $(0.145)$ & $(0.071)$ \\
\hline \multirow[t]{2}{*}{ oldage(t-1) } & 0.204 & 0.165 & 0.498 & 0.448 & $0.193^{* *}$ & $0.213^{* *}$ & 0.067 & 0.051 \\
\hline & $(0.122)$ & $(0.207)$ & $(0.148)$ & $(0.207)$ & $(0.025)$ & $(0.011)$ & $(0.269)$ & $(0.398)$ \\
\hline \multirow[t]{2}{*}{ govparty } & -0.061 & -0.056 & -0.054 & -0.054 & -0.018 & -0.003 & -0.004 & -0.012 \\
\hline & $(0.235)$ & $(0.288)$ & $(0.641)$ & $(0.638)$ & $(0.629)$ & $(0.925)$ & $(0.846)$ & $(0.618)$ \\
\hline \multirow[t]{2}{*}{ L.socexp } & $0.724 * * *$ & $0.702 * * *$ & & & & & & \\
\hline & $(0.000)$ & $(0.000)$ & & & & & & \\
\hline \multirow[t]{2}{*}{ L.ITR capital } & & & $0.742 * * *$ & $0.741 * * *$ & & & & \\
\hline & & & $(0.000)$ & $(0.000)$ & & & & \\
\hline \multirow[t]{2}{*}{ L.ITR labour } & & & & & $0.717^{* * *}$ & $0.716 * * *$ & & \\
\hline & & & & & $(0.000)$ & $(0.000)$ & & \\
\hline \multirow[t]{2}{*}{ L.ITR consumption } & & & & & & & $0.833^{* * *}$ & $0.834 * * *$ \\
\hline & & & & & & & $(0.000)$ & $(0.000)$ \\
\hline r2 & 0.821 & 0.823 & 0.702 & 0.702 & 0.931 & 0.931 & 0.837 & 0.837 \\
\hline$N$ & 268 & 268 & 381 & 381 & 399 & 399 & 399 & 399 \\
\hline ftestTD & 0.000 & 0.000 & 0.001 & 0.001 & 0.226 & 0.050 & 0.000 & 0.000 \\
\hline
\end{tabular}

Newey-West-HAC robust p-values in parentheses; estimates based on Schaffer's xtivreg2 command with bw(2) robust option; F-test TD $=p$-values of test of significance of time dummies; socexp: social protection expenditures as share of total expenditures, ITR cap: implicit tax rate on capital income, ITR lab: ITR on labour income, ITR con: ITR on consumption; $* \mathrm{p}<0.10, * * \mathrm{p}<0.05, * * * \mathrm{p}<0.01$

*1980-2007 for social expenditures 
Table 2. Estimation results for the EU15 - 4 regimes, 1970 - 2007*

\begin{tabular}{|c|c|c|c|c|c|c|c|c|}
\hline & (1) & (2) & (3) & (4) & (5) & (6) & (7) & (8) \\
\hline & socexp & socexp & itr_cap & itr_cap & itr_lab & itr_lab & itr_con & itr_con \\
\hline & $b / p$ & $b / p$ & $b / p$ & $b / p$ & $b / p$ & $b / p$ & $b / p$ & $b / p$ \\
\hline \multirow[t]{2}{*}{ KOFglobal(t-1) } & $0.115^{* * *}$ & & 0.061 & & $0.051^{*}$ & & -0.031 & \\
\hline & $(0.002)$ & & $(0.478)$ & & $(0.069)$ & & $(0.121)$ & \\
\hline \multirow[t]{2}{*}{ KOFglobal*socdem( 1$)$} & $-0.189 * * *$ & & $-0.441^{* *}$ & & -0.013 & & -0.002 & \\
\hline & $(0.001)$ & & $(0.022)$ & & $(0.791)$ & & (0.965) & \\
\hline \multirow[t]{2}{*}{ KOFglobal*south(t-1) } & -0.076 & & $-0.174 *$ & & $-0.087^{* *}$ & & 0.002 & \\
\hline & $(0.185)$ & & $(0.094)$ & & $(0.023)$ & & $(0.963)$ & \\
\hline \multirow[t]{2}{*}{ KOFglobal*lib(t-1) } & $-0.417 * * *$ & & -0.185 & & -0.065 & & -0.017 & \\
\hline & $(0.000)$ & & (0.199) & & $(0.138)$ & & (0.609) & \\
\hline \multirow[t]{2}{*}{ KOFecon(t-1) } & & 0.044 & & 0.005 & & $0.045^{* *}$ & & $-0.033^{* *}$ \\
\hline & & $(0.212)$ & & $(0.952)$ & & $(0.016)$ & & $(0.042)$ \\
\hline \multirow[t]{2}{*}{ KOFecon*socdem(t-1) } & & -0.055 & & $-0.212^{*}$ & & 0.031 & & -0.002 \\
\hline & & $(0.115)$ & & $(0.070)$ & & $(0.306)$ & & $(0.952)$ \\
\hline \multirow[t]{2}{*}{ KOFecon*south(t-1) } & & $-0.107^{* *}$ & & 0.023 & & -0.007 & & 0.026 \\
\hline & & $(0.024)$ & & $(0.848)$ & & $(0.854)$ & & $(0.375)$ \\
\hline \multirow[t]{2}{*}{ KOFecon*lib(t-1) } & & -0.117 & & 0.263 & & 0.021 & & $0.056^{*}$ \\
\hline & & $(0.134)$ & & $(0.207)$ & & $(0.618)$ & & $(0.096)$ \\
\hline \multirow[t]{2}{*}{ size(t-1) } & 0.004 & 0.026 & $1.185^{* *}$ & $0.951^{* *}$ & 0.062 & 0.049 & -0.014 & -0.062 \\
\hline & $(0.988)$ & $(0.922)$ & (0.017) & $(0.035)$ & $(0.589)$ & $(0.643)$ & $(0.883)$ & $(0.497)$ \\
\hline \multirow[t]{2}{*}{ growth(t-1) } & $-0.145 * * *$ & $-0.190 * * *$ & $0.197^{*}$ & 0.156 & 0.017 & 0.002 & $0.047^{*}$ & $0.049 *$ \\
\hline & $(0.002)$ & $(0.000)$ & $(0.076)$ & (0.179) & $(0.603)$ & $(0.945)$ & $(0.084)$ & $(0.082)$ \\
\hline \multirow[t]{2}{*}{ inflation(t-1) } & 0.005 & -0.027 & 0.025 & 0.001 & $0.067^{* * *}$ & $0.057^{* *}$ & 0.025 & 0.026 \\
\hline & $(0.919)$ & $(0.591)$ & $(0.802)$ & (0.995) & $(0.003)$ & $(0.012)$ & $(0.303)$ & $(0.270)$ \\
\hline \multirow[t]{2}{*}{ expenditure(t-1) } & $0.118^{* * *}$ & $0.071^{*}$ & 0.005 & -0.002 & $0.117^{* * *}$ & $0.108^{* * *}$ & 0.012 & 0.015 \\
\hline & $(0.004)$ & $(0.074)$ & $(0.933)$ & $(0.976)$ & $(0.000)$ & $(0.000)$ & $(0.413)$ & $(0.327)$ \\
\hline \multirow[t]{2}{*}{$\operatorname{debt}(\mathrm{t}-1)$} & 0.002 & -0.007 & 0.001 & 0.004 & $0.020 * * *$ & $0.023^{* * *}$ & -0.006 & -0.007 \\
\hline & $(0.807)$ & $(0.444)$ & $(0.955)$ & $(0.817)$ & $(0.001)$ & $(0.000)$ & $(0.145)$ & (0.119) \\
\hline \multirow[t]{2}{*}{ oldage(t-1) } & 0.047 & 0.180 & 0.404 & 0.070 & -0.131 & $-0.192^{*}$ & -0.054 & -0.071 \\
\hline & $(0.805)$ & $(0.335)$ & $(0.373)$ & $(0.875)$ & $(0.199)$ & $(0.080)$ & (0.549) & $(0.434)$ \\
\hline \multirow[t]{2}{*}{ govparty } & -0.012 & -0.026 & -0.025 & -0.006 & -0.047 & -0.039 & 0.006 & -0.005 \\
\hline & $(0.832)$ & $(0.635)$ & $(0.824)$ & $(0.953)$ & $(0.172)$ & $(0.248)$ & $(0.821)$ & $(0.862)$ \\
\hline \multirow[t]{2}{*}{ trend_socialdem } & $0.222 * * *$ & $0.092^{* *}$ & $0.466^{* * *}$ & $0.338^{* *}$ & -0.022 & $-0.084^{* *}$ & 0.006 & 0.017 \\
\hline & $(0.000)$ & $(0.034)$ & $(0.007)$ & $(0.022)$ & $(0.623)$ & $(0.032)$ & $(0.856)$ & $(0.597)$ \\
\hline \multirow[t]{2}{*}{ trend_southern } & $0.135^{* *}$ & $0.162 * *$ & $0.344 * *$ & 0.132 & $0.232 * * *$ & $0.150 * * *$ & 0.049 & 0.017 \\
\hline & $(0.050)$ & $(0.018)$ & $(0.019)$ & $(0.428)$ & $(0.000)$ & $(0.005)$ & $(0.261)$ & $(0.641)$ \\
\hline \multirow[t]{2}{*}{ trend_liberal } & $0.279 * * *$ & 0.005 & 0.116 & -0.190 & 0.052 & -0.014 & -0.005 & $-0.048^{*}$ \\
\hline & $(0.002)$ & $(0.925)$ & $(0.316)$ & $(0.239)$ & $(0.173)$ & $(0.672)$ & $(0.848)$ & $(0.070)$ \\
\hline $\operatorname{socexp}(t-1)$ & $0.588 * * *$ & $0.666^{* * *}$ & & & & & & \\
\hline & $(0.000)$ & $(0.000)$ & & & & & & \\
\hline ITR capital(t-1) & & & $0.685^{* * *}$ & $0.706^{* * *}$ & & & & \\
\hline & & & $(0.000)$ & $(0.000)$ & & & & \\
\hline ITR labor(t-1) & & & & & $0.654^{* * *}$ & $0.625^{* * *}$ & & \\
\hline & & & & & $(0.000)$ & $(0.000)$ & & \\
\hline ITR consumption(t-1) & & & & & & & $0.806^{* * *}$ & $0.799 * * *$ \\
\hline & & & & & & & $(0.000)$ & $(0.000)$ \\
\hline$r 2$ & 0.844 & 0.832 & 0.720 & 0.720 & 0.937 & 0.938 & 0.841 & 0.841 \\
\hline $\mathrm{N}$ & 268 & 268 & 381 & 381 & 399 & 399 & 399 & 399 \\
\hline ftestTD & 0.000 & 0.000 & 0.000 & 0.000 & 0.046 & 0.012 & 0.000 & 0.000 \\
\hline ftest_socialdem & 0.150 & 0.680 & 0.023 & 0.054 & 0.409 & 0.002 & 0.328 & 0.096 \\
\hline ftest_south & 0.431 & 0.110 & 0.196 & 0.764 & 0.268 & 0.293 & 0.351 & 0.796 \\
\hline ftest_liberal & 0.000 & 0.296 & 0.290 & 0.119 & 0.692 & 0.059 & 0.103 & 0.401 \\
\hline
\end{tabular}

Newey-West-HAC robust p-values in parentheses; estimates based on Schaffer's xtivreg2 command with bw(2) robust option; F-test TD = pvalues of test of significance of time dummies; socexp: social protection expenditures as share of total expenditures, ITR cap: implicit tax rate on capital income, ITR lab: ITR on labour income, ITR con: ITR on consumption; * $\mathrm{p}<0.10, * * \mathrm{p}<0.05, * * * \mathrm{p}<0.01$

*1980-2007 for social expenditures 
Table 3. Estimation results for the CEENMS, 1995-2007

\begin{tabular}{|c|c|c|c|c|c|c|c|c|}
\hline & (1) & $(2)$ & (3) & (4) & (5) & (6) & (7) & (8) \\
\hline & socexp & socexp & itr_cap & itr_cap & itr_lab & itr_lab & itr_con & itr_con \\
\hline & $b / p$ & $b / p$ & $\mathrm{~b} / \mathrm{p}$ & $\mathrm{b} / \mathrm{p}$ & $\mathrm{b} / \mathrm{p}$ & $\mathrm{b} / \mathrm{p}$ & $\mathrm{b} / \mathrm{p}$ & $\mathrm{b} / \mathrm{p}$ \\
\hline \multirow[t]{2}{*}{ KOFglobal(t-1) } & 0.213 & & 0.088 & & -0.045 & & $-0.116^{*}$ & \\
\hline & $(0.304)$ & & $(0.412)$ & & $(0.562)$ & & $(0.067)$ & \\
\hline \multirow[t]{2}{*}{ KOFecon(t-1) } & & 0.089 & & $0.099 *$ & & 0.026 & & $-0.070 * *$ \\
\hline & & (0.277) & & $(0.083)$ & & $(0.444)$ & & $(0.026)$ \\
\hline \multirow[t]{2}{*}{ size(t-1) } & $-24.661 * *$ & $-24.168 * *$ & 1311 & -1133 & 1522 & 1649 & -2142 & 0.077 \\
\hline & (0.019) & $(0.016)$ & (0.840) & (0.849) & $(0.729)$ & (0.665) & (0.659) & (0.987) \\
\hline \multirow[t]{2}{*}{ growth(t-1) } & $-0.236 *$ & $-0.214^{*}$ & 0.092 & 0.108 & $-0.122 * *$ & $-0.127 * *$ & -0.013 & -0.032 \\
\hline & $(0.074)$ & (0.094) & $(0.358)$ & $(0.260)$ & $(0.045)$ & $(0.040)$ & $(0.770)$ & $(0.485)$ \\
\hline \multirow[t]{2}{*}{ inflation(t-1) } & -0.109 & -0.093 & $0.061^{*}$ & $0.061^{*}$ & $-0.074 * * *$ & $-0.073 * * *$ & 0.010 & 0.007 \\
\hline & $(0.143)$ & (0.208) & $(0.054)$ & $(0.056)$ & $(0.001)$ & $(0.002)$ & $(0.521)$ & (0.640) \\
\hline \multirow[t]{2}{*}{ expenditure(t-1) } & 0.027 & 0.028 & -0.075 & -0.076 & 0.042 & 0.047 & $0.087^{* *}$ & $0.088^{* *}$ \\
\hline & $(0.832)$ & $(0.827)$ & $(0.361)$ & $(0.342)$ & $(0.345)$ & $(0.304)$ & $(0.015)$ & $(0.013)$ \\
\hline \multirow[t]{2}{*}{$\operatorname{debt}(t-1)$} & 0.022 & 0.021 & 0.023 & 0.023 & $0.050 * *$ & $0.048^{* *}$ & $-0.037^{* *}$ & $-0.038 * * *$ \\
\hline & $(0.544)$ & $(0.583)$ & $(0.241)$ & $(0.228)$ & $(0.011)$ & (0.017) & $(0.011)$ & (0.006) \\
\hline \multirow[t]{2}{*}{ oldage(t-1) } & $-2.129 * * *$ & $-1.811^{* *}$ & 0.828 & $1.089 * *$ & -0.323 & -0.303 & -0.134 & -0.357 \\
\hline & $(0.005)$ & $(0.026)$ & $(0.137)$ & $(0.040)$ & $(0.294)$ & $(0.384)$ & (0.660) & $(0.235)$ \\
\hline \multirow[t]{2}{*}{ govparty } & $-0.499 *$ & $-0.491^{*}$ & 0.049 & 0.014 & -0.120 & -0.121 & $-0.263^{* *}$ & $-0.249 * *$ \\
\hline & $(0.076)$ & $(0.072)$ & $(0.639)$ & $(0.895)$ & $(0.242)$ & $(0.228)$ & $(0.021)$ & $(0.029)$ \\
\hline \multirow[t]{2}{*}{ L.socexp } & $0.401^{* * *}$ & $0.412^{* * *}$ & & & & & & \\
\hline & $(0.008)$ & $(0.007)$ & & & & & & \\
\hline \multirow[t]{2}{*}{ L.ITR capital } & & & $0.848^{* * *}$ & $0.851^{* * *}$ & & & & \\
\hline & & & $(0.000)$ & $(0.000)$ & & & & \\
\hline \multirow[t]{2}{*}{ L.ITR Iabour } & & & & & $0.529 * * *$ & $0.526 * * *$ & & \\
\hline & & & & & (0.000) & (0.000) & & \\
\hline \multirow[t]{2}{*}{ L.ITR consumption } & & & & & & & $0.460 * * *$ & $0.458 * * *$ \\
\hline & & & & & & & $(0.000)$ & $(0.000)$ \\
\hline$r 2$ & 0.539 & 0.538 & 0.726 & 0.734 & 0.737 & 0.737 & 0.673 & 0.679 \\
\hline$N$ & 84 & 84 & 101 & 101 & 108 & 108 & 108 & 108 \\
\hline ftestTD & 0.162 & 0.214 & 0.375 & 0.347 & 0.106 & 0.022 & 0.000 & 0.000 \\
\hline
\end{tabular}

Newey-West-HAC robust p-values in parentheses; estimates based on Schaffer's xtivreg2 command with bw(2) robust option; F-test $\mathrm{TD}=\mathrm{p}$-values of test of significance of time dummies; socexp: social protection expenditures as share of total expenditures, ITR cap: implicit tax rate on capital income, ITR lab: ITR on labour income, ITR con: ITR on consumption; $* \mathrm{p}<0.10, * * \mathrm{p}<0.05, * * * \mathrm{p}<0.01$ 
Table 4. Estimation results for the CEENMS - 2 regimes, 1995-2007

\begin{tabular}{|c|c|c|c|c|c|c|c|c|}
\hline & (1) & (2) & (3) & (4) & (5) & (6) & (7) & (8) \\
\hline & socexp & socexp & itr_cap & itr_cap & itr_lab & itr_lab & itr_con & itr_con \\
\hline & $\mathrm{b} / \mathrm{p}$ & $b / p$ & $b / p$ & $b / p$ & $\mathrm{~b} / \mathrm{p}$ & $\mathrm{b} / \mathrm{p}$ & $\mathrm{b} / \mathrm{p}$ & $\mathrm{b} / \mathrm{p}$ \\
\hline \multirow[t]{2}{*}{ KOFglobal(t-1) } & $0.397^{*}$ & & -0.050 & & -0.066 & & -0.108 & \\
\hline & $(0.076)$ & & $(0.769)$ & & $(0.501)$ & & $(0.164)$ & \\
\hline \multirow[t]{2}{*}{ KOFglobal*baltic } & $-0.684 * * *$ & & 0.265 & & -0.096 & & -0.036 & \\
\hline & $(0.005)$ & & $(0.395)$ & & $(0.578)$ & & $(0.836)$ & \\
\hline \multirow[t]{2}{*}{ KOFecon(t-1) } & & 0.147 & & 0.041 & & -0.014 & & $-0.078 * *$ \\
\hline & & $(0.127)$ & & $(0.605)$ & & $(0.744)$ & & $(0.022)$ \\
\hline \multicolumn{2}{|c|}{ KOFecon*baltic(t-1) } & $-0.249 * *$ & & 0.188 & & -0.100 & & -0.038 \\
\hline & & $(0.037)$ & & $(0.262)$ & & $(0.292)$ & & $(0.704)$ \\
\hline \multirow[t]{2}{*}{$\operatorname{size}(t-1)$} & $-23.593 * *$ & $-23.851 * *$ & -4371 & -3274 & -2649 & -1673 & -2143 & -0.746 \\
\hline & $(0.028)$ & $(0.016)$ & (0.599) & $(0.622)$ & $(0.597)$ & $(0.686)$ & $(0.668)$ & $(0.875)$ \\
\hline \multirow[t]{2}{*}{ growth(t-1) } & -0.179 & -0.194 & 0.112 & 0.101 & -0.057 & -0.063 & -0.008 & -0.014 \\
\hline & $(0.153)$ & $(0.127)$ & $(0.263)$ & (0.293) & $(0.338)$ & $(0.280)$ & $(0.868)$ & $(0.774)$ \\
\hline \multirow[t]{2}{*}{ inflation(t-1) } & $-0.126^{*}$ & -0.113 & $0.076 * * *$ & $0.073 * *$ & $-0.065 * * *$ & $-0.066 * * *$ & 0.009 & 0.008 \\
\hline & $(0.074)$ & $(0.125)$ & $(0.009)$ & $(0.011)$ & $(0.003)$ & $(0.003)$ & $(0.584)$ & $(0.601)$ \\
\hline \multirow[t]{2}{*}{ expenditure(t-1) } & 0.094 & 0.063 & -0.111 & -0.095 & 0.024 & 0.025 & $0.091^{* *}$ & $0.085 * *$ \\
\hline & $(0.450)$ & $(0.616)$ & $(0.270)$ & $(0.267)$ & $(0.615)$ & $(0.572)$ & $(0.042)$ & $(0.035)$ \\
\hline \multirow[t]{2}{*}{$\operatorname{debt}(\mathrm{t}-1)$} & 0.014 & 0.019 & 0.031 & 0.027 & $0.057^{* * *}$ & $0.056^{* * *}$ & $-0.037^{* * *}$ & $-0.037 * * *$ \\
\hline & $(0.703)$ & (0.595) & (0.164) & (0.179) & $(0.002)$ & $(0.003)$ & $(0.008)$ & $(0.006)$ \\
\hline \multirow[t]{2}{*}{ oldage(t-1) } & $-2.854 * *$ & $-2.797 * *$ & $1.811^{* *}$ & $1.586^{* *}$ & $0.817 * *$ & $0.755^{* *}$ & -0.100 & -0.094 \\
\hline & $(0.015)$ & $(0.020)$ & $(0.013)$ & $(0.016)$ & $(0.033)$ & $(0.031)$ & $(0.805)$ & $(0.801)$ \\
\hline \multirow[t]{2}{*}{ govparty } & -0.442 & -0.432 & -0.038 & -0.045 & $-0.171^{* *}$ & $-0.155^{*}$ & $-0.260 * *$ & $-0.255^{* *}$ \\
\hline & $(0.162)$ & $(0.149)$ & $(0.761)$ & $(0.708)$ & $(0.041)$ & $(0.055)$ & $(0.029)$ & $(0.023)$ \\
\hline \multirow[t]{2}{*}{ trend*baltic } & $1.071^{* *}$ & 0.628 & -0.628 & -0.450 & -0.193 & -0.185 & 0.039 & -0.026 \\
\hline & $(0.014)$ & $(0.101)$ & $(0.241)$ & $(0.216)$ & $(0.480)$ & $(0.304)$ & $(0.900)$ & $(0.901)$ \\
\hline \multirow[t]{2}{*}{ L.socexp } & $0.389 * * *$ & $0.419 * * *$ & & & & & & \\
\hline & $(0.003)$ & $(0.004)$ & & & & & & \\
\hline \multirow[t]{2}{*}{ L.ITR capital } & & & $0.800 * * *$ & $0.816 * * *$ & & & & \\
\hline & & & $(0.000)$ & $(0.000)$ & & & & \\
\hline \multirow[t]{2}{*}{ L.ITR labour } & & & & & $0.531 * * *$ & $0.527^{* * *}$ & & \\
\hline & & & & & $(0.000)$ & $(0.000)$ & & \\
\hline \multirow[t]{2}{*}{ L.ITR consumption } & & & & & & & $0.459 * * *$ & $0.452 * * *$ \\
\hline & & & & & & & $(0.000)$ & $(0.000)$ \\
\hline r2 & 0.564 & 0.551 & 0.735 & 0.740 & 0.766 & 0.765 & 0.674 & 0.683 \\
\hline $\mathrm{N}$ & 84 & 84 & 101 & 101 & 108 & 108 & 108 & 108 \\
\hline ftestTD & 0.158 & 0.249 & 0.373 & 0.350 & 0.203 & 0.118 & 0.000 & 0.000 \\
\hline ftest_baltic & 0.191 & 0.435 & 0.280 & 0.093 & 0.180 & 0.170 & 0.310 & 0.216 \\
\hline
\end{tabular}

Newey-West-HAC robust p-values in parentheses; estimates based on Schaffer's xtivreg2 command with bw(2) robust option; F-test TD $=$ p-values of test of significance of time dummies; socexp: social protection expenditures as share of total expenditures, ITR cap: implicit tax rate on capital income, ITR lab: ITR on labour income, ITR con: ITR on consumption; * $\underline{\mathrm{p}<0.10, * * \mathrm{p}<0.05, * * * \mathrm{p}<0.01}$ 


\section{Appendix}

Table A.1. Data Sources and description

\begin{tabular}{|c|c|c|c|}
\hline KOFglobal & $\begin{array}{l}\text { index of economic, political and social globalization, ranging from } 1 \\
\text { to } 100\end{array}$ & \begin{tabular}{|l} 
Dreher (2006b), updated in \\
Dreher et. al (2008a)
\end{tabular} & $1970-2007$ \\
\hline KOFecon & $\begin{array}{l}\text { index of economic globalization, combining actual flows and } \\
\text { restrictions }\end{array}$ & $\begin{array}{l}\text { Dreher (2006b), updated in } \\
\text { Dreher et. al (2008a) }\end{array}$ & 1970-2007 \\
\hline growth & growth rate of real GDP & AMECO database & 1970-2007 \\
\hline debt & general government consolidated gross debt as a percentage of GDP & AMECO database & 1970-2007 \\
\hline inflation & inflation (GDP deflator) & AMECO database & 1970-2007 \\
\hline expenditure & total expenditures of general government as a percentage of GDP & AMECO database & 1970-2007 \\
\hline oldage & fraction of elderly people $(>64)$ in total population & AMECO database & 1970-2007 \\
\hline govparty & $\begin{array}{l}\text { government cabinet composition (Schmidt-Index) ranging from (1) } \\
\text { hegemony of right wind (and centre) parties to (5) hegemony of } \\
\text { social-democratic and left barties }\end{array}$ & $\begin{array}{l}\text { Comparative Political Dataset } \\
\text { I and III, University of Bern }\end{array}$ & 1970-2007 \\
\hline size & GDP of a country as share of the sample GDP & AMECO database & 1970-2007 \\
\hline ITR_cap & implicit tax rate on capital income & $\begin{array}{l}\text { Eurostat, European } \\
\text { Commission }\end{array}$ & 1970-2007 \\
\hline ITR_lab & implicit tax rate on labor income & $\begin{array}{l}\text { Eurostat, European } \\
\text { Commission }\end{array}$ & 1970-2007 \\
\hline ITR_con & implicit tax rate on consumption & $\begin{array}{l}\text { Eurostat, European } \\
\text { Commission }\end{array}$ & 1970-2007 \\
\hline socexp & social protection expenditures as share of total public expenditures & $\begin{array}{l}\text { Eurostat, OECD National } \\
\text { Accounts Vol. II }\end{array}$ & 1980-2007 \\
\hline
\end{tabular}

